\title{
Arapçada 'Mâ' Edatının Anlam Türleri: Amme Cüzü Örneği
}

\author{
Osman Aktaş \\ Dr. Öğr. Üyesi, Ankara Sosyal Bilimler Üniversitesi (ROR ID: 025y36b60) \\ İslami İlimler Fakültesi, Temel İslam Bilimleri Bölümü \\ Assist. Prof. Dr., Social Sciences University of Ankara, Faculty of Islamic Studies \\ Department of Basic Islamic Sciences \\ Ankara/Turkey \\ osman.aktas@asbu.edu.tr \\ ORCID: 0000-0002-9217-6171
}

\section{Luay Hatem Yaqoob}

Dr. Öğr. Üyesi, Ankara Sosyal Bilimler Üniversitesi (ROR ID: 025y36b60)

İslami İlimler Fakültesi, Temel İslam Bilimleri Bölümü

Assist. Prof. Dr., Social Sciences University of Ankara, Faculty of Islamic Studies

Department of Basic Islamic Sciences

Ankara/Turkey

luay.hatem@asbu.edu.tr

ORCID: 0000-0002-8518-0148

\section{Functions and Meanings of 'Mā' Preposition in the Arabic Language, The 30th Part of the Qur'ān, As A Model}

\begin{abstract}
The prepositions in the Arabic language have an important place in understanding compound sentences. Researchers and authors have taken particular care of it. The preposition mā is one of the joining tools with multiple meanings and functions, as grammarians have used it for ten different functions and meanings. What determines the function and meaning of the preposition mā is its place and location in the sentence. Every kind of mā preposition has specific rules and meanings itself. As it is known, the word in the Arabic language is divided into a noun, verb, and a letter (according to the old classical division). This study found that the preposition mā had used a noun and a letter. This study contains two main chapters. The first chapter that dealt with the various and different uses of the mā; as for the second chapter, it dealt with the types of mā mentioned in the 30th juzz' (part) of the Qur'ān. This study revealed the fact that mā was mentioned seventy times, in addition to being mentioned 19 times, and it has more than one connotation and a grammatical function.
\end{abstract}

İtihal Taraması/Plagiarism Detection: Bu makale intihal taramasından geçirildi/This paper was checked for plagiarism Etik Beyan/Ethical Statement: Bu çalışmanın hazırlanma sürecinde bilimsel ve etik ilkelere uyulduğu ve yararlanılan tüm çalışmaların kaynakçada belirtildiği beyan olunur/It is declared that scientific and ethical principles have been followed while carrying out and writing this study and that all the sources used have been properly cited (Osman Aktaş, Luay Hatem Yaqoob).

Geliş/Received: 08 Haziran/June 2021 | Kabul/Accepted: 06 Eylül/September 2021 | Yayın/Published: 20 Eylül/September 2021 Atıf/Cite as: Osman Aktaş, Luay Hatem Yaqoob, "Arapçada 'Mâ' Edatının Anlam Türleri: Amme Cüzü Örneği = Functions and Meanings of 'Mā' Preposition in the Arabic Language, The 30th Part of the Qur'ān, As A Model”, Eskiyeni 44 (Eylül/September 2021), 645-661. https://doi.org/10.37697/eskiyeni.949558

CC BY-NC 4.0 | This paper is licensed under a Creative Commons Attribution-NonCommercial License 
As a result of the conducted research, it is confirmed that mā has six different types. The types of mā used as a letter are mā al-nafiyah (negative mā), mā used as laysa (the mā that resembles), mā al-kāffah (preventative mā), mā al-za'idah (extra mā), mā al-ibhamiyah (indefinite mā) and mā al-mașdariyah (gerundival mā). Besides that, it is found out that there are four types of mā used as a noun. Mā al-istifhamiyah (interrogative mā), mā al-ta'ajubiyah (exclamation mā), mā al-sharțiyah (conditional mā) and mā al-mawșulah (pronominal mā) are the kinds of mā used as a noun. Whereas there is an agreement about some of the grammatical cases of mā mentioned in 'Amma juz' of the Qur'ān, there are conflicts in some of them. The number of mā mentioned in 'Amma juz' is fifty-one that are agreed in terms of grammatical cases. Besides that, the number of mā which there is disagreement over its grammatical issues is nineteen.

Mā al-sharțiyah and mā al-ibhamiyah are not mentioned in 'Amma juz' of Qur'ān. Except for these types, all kind of mā is mentioned in 'Amma juz'. Mā al-istifhamiyah is mentioned seventeen times in 'Amma juz', from this aspect it is the most mentioned and most agreed type of mā in terms of grammatical case. In 'Amma juz', the kinds of mā al-mawșulah and mā almașdariyah can possibly be discussed in two different ways regarding grammatical matters at the same time. The number of possible parts that grammatically probable to evaluate in two different ways is fifteen. The presence of ten different types of the mā preposition with shows the richness of Arabic language. In this study, the wealth of Arabic language in the Qur'ān is tried to be demonstrated.

\section{Keywords}

Arabic, Indication of the Prepositions, Preposition Mā, Types of Prepositions Mā, Juzz' 'Amma

\section{Öz}

\section{Arapçada 'Mâ' Edatının Anlam Türleri: Amme Cüzü Örneği}

Arapçada edatlar, özellikle bileşik cümleleri anlamada çok önemli bir yere sahiptir. Öyle ki, Arap dili alanında araştırma yapan ve eser telif edenler tarafından önem verilen konuların başında gelmektedir. Mâ edatı, bahsi geçen edatlardan olup nahiv bilginleri tarafından on farklı anlam ve görevde kullanıldığı tespit edilmiştir. Mâ edatının farklı anlam ve görevlerde kullanıldığını gösteren husus ise, edatın cümle içindeki konumudur. Mâ edatının her bir türünün kendine has şartları ve anlamları söz konusudur. Arapçada klasik tasnife göre kelime; isim, fiil ve harf olmak üzere üçe ayrılır. Bu araştırmada mâ edatının isim ve harf olmak üzere iki farklı görevde kullanıldığı tespit edilmiştir. Bu çalışma, iki ana bölümden oluşmaktadır. Birinci bölümde mâ edatının farklı görev ve anlamlarda kullanılması; ikinci bölümde ise mâ edatının amme cüzündeki kullanım türleri ele alınmıştır. Yapılan araştırmada mâ edatının amme cüzünde yetmiş defa zikredildiği tespit edilmiştir. Amme cüzünde zikredilen mâ edatının on dokuz yerdeki irab ve delaleti ile ilgili farklı görüşlerin ileri sürüldüğü görülmüştür.

Yapılan araştırmada harf olarak kullanılan mâ edatının altı farklı türünün olduğu tespit edilmiştir. Harf olarak kullanılan mâ edatları; mâ en-nâfiye, leyse gibi amel eden mâ, mâ el-kâffe, mâ ez-zâide, mâ el-ibhâmiyye ve mâ el-masdariyye'dir. İsim olarak kullanılan mâ edatının ise dört farklı türünün olduğu tespit edilmiştir. İsim olarak kullanılan mâ edatları; mâ elistifhâmiyye, mâ et-ta'accubiyye, mâ eş-şartiyye ve mâ el-mevsûle'dir. Amme cüzünde geçen mâ edatlarının bazısının irabında ittifak edilmişken bazısında da ihtilafa düşülmüştür. Amme cüzünde geçen ve irabı konusunda ittifak bulunan mâ edatlarının sayısı elli birdir. Amme cüzünde geçen ve irabı konusunda ihtilaf bulunan mâ edatlarının sayısı ise on dokuzdur. Mâ 
eş-şartiyye ve mâ el-ibhâmiyye Amme cüzünde zikredilmemiştir. Geri kalan bütün mâ edatı türleri ise Amme cüzünde zikredilmiştir. Amme cüzünde on yedi defa zikredilen mâ elistifhâmiyye Amme cüzünde en fazla zikredilen ve irabı konusunda en fazla ittifak bulunan mâ edatı türüdür. Amme cüzünde aynı anda iki farklı şekilde irab olunması mümkün olan mâ edatı türleri mâ el-mevsûle ve mâ el-masdariyye'dir. Her iki şekilde irab olması mümkün olan yer sayısı ise on beştir. Mâ edatının on farklı türünün bulunması Arap dilinin zenginliğini göstermektedir. Bu çalışmada Arap dilinin bu zenginliğinin Kur'ân-1 Kerîm'de varlık bulduğu gösterilmeye çalışılmıştır.

\section{Anahtar Kelimeler}

Arapça, Edatların Delâleti, Mâ Edatı, Mâ Edatı Türleri, Amme Cüzü

\section{Giriş}

Dil, insanoğlunun tarihi kadar geçmişi olan bir olgudur. İnsanoğlu varlık sahasında göründüğünden beri, dil de var olagelmiştir. İnsanlar, duygu ve düşüncelerini etkili bir şekilde ifade etmede, bilim ve sanat üretmede de dile ihtiyaç duymuştur. Bu bağlamda dil, kişiler arası iletişimin temel unsuru olmuştur. Zira, doğası gereği sosyal bir varlık olan insan, başka insanlarla iletişim kurmaya ihtiyaç duymuştur.

Öğretmen sınıfta ders anlatırken, bilim insanı bilimsel bir toplantıda sunum yaparken, şair şiir yazarken, senarist film senaryosu yazarken, vaiz kürsüde vaaz ederken dilin kapısını çalar. Bu ifadeler her zaman bir çocuğun su istemesi gibi tek yüklemli basit cümleler olmaz, bazen bileşik ve karmaşık cümleler kurulur. Bileşik cümleler kurulurken yan cümleyi temel cümleye bağlayan edatlardan yararlanılır.

İster yazılı ister sözlü olsun, bir meram anlatılırken doğru bir şekilde anlaşılması istenir. Bu noktada edatların ve cümlede yerine getirdiği görevlerinin bilinmesinin büyük bir önemi vardır. Klasik dönem nahiv eserlerinde, tefsir ve fikıh kitaplarında edatların anlamlarına ve bu görevlere önemle yer verildiği görülmektedir. Bunun yanı sıra edatların anlamlarından hareketle tefsir ve fikıh gibi İslami ilimlerde bazı ihtilafların vuku bulduğu da bilinmektedir. ${ }^{1}$

Arapçada edatlar konusu çerçevesinde öne çıkan bir husus; bazı edatların, cümle içindeki konumuna göre farklı görev ve anlamlarda kullanılabildiğidir. Bu edatlardan biri de bu çalışmada ele alınan mâ (مَ) edatıdır. ما edatı; altısı harf ve dördü isim olmak üzere on farklı anlam ve görevde kullanılmaktadır: ${ }^{2}$ İsim ve harf olan ما edatı; isim, fiil ve cümlelerin başına gelebilmektedir. Her birinin cümle içindeki konumuna göre farklı anlam ve görevleri bulunmaktadır.

Bir sonraki bölümde bu edatın farklı anlam ve görevleri incelenmiştir. Öncelikle harf olarak ve ardından isim olarak kullanılan odatına yer verilmiştir. Sonraki bölüm ise Amme cüzünde geçen s edatının çeşitlerini ele almaktadır.

Abdullah Hacibekiroğlu, Arap Dilinde Edatların Metinde Kurduğu Anlamsal İlşskiler (Ankara: Yıldııım Beyazıt Üniversitesi, Doktora Tezi, 2015), xvii.

2 Abduh er-Râcihî, et-Tatbîku'n-nahvî (Beyrut: Dâru'n-Nahdati'l-'Arabiyye, 1431/2010), 14-16; Ebü'l-Hasen Alî b. Îsâ er-Rummânî, Menâzili'l-hurûf (Beyrut: el-Mektebetü'l-'Asriyye, 2005), 59-63. 


\section{Harf Olarak Kullanılan L Edat1}

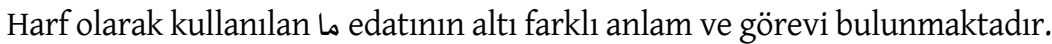

\subsection{Mâ en-Nâfiye (مَا النَّافِيَّة)}

Nefy harfi olarak kullanılan o edatı hem mazi hem de muzari fiili nefyeder ve yapı bakımından fiili olumsuza dönüştürür. ${ }^{3}$ Bu kapsamda $L$ edatı, muzari fiili nefy ettiğinde, fiilin irabına etki etmez. Mazi fiil mebnî olduğu için L edatının mazi fiilde amel etmesi söz konusu olamaz. Örnekler

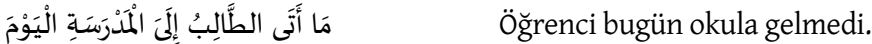

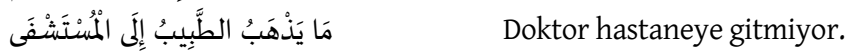

\section{2. (مَا الْعَامِلَةُ عَمَلَ لَيَسنَ) مَا Gibi Amel eden كَيْنَ}

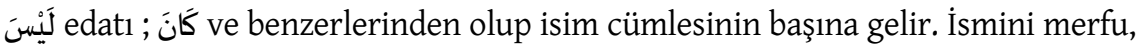
haberini mansub yapar. ${ }^{4}$ Benzer şekilde ô edatının da لَّبَ anlamında kullanılabildiği ve bu durumda ليس'nin hükmünü alarak ismini merfu, haberini mansub yaptığı belirtilmiştir. ${ }^{5}$ Örnekler:

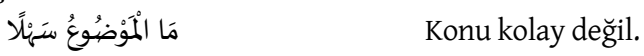

$$
\begin{aligned}
& \text { مَا مَا الطَّرِقُ طَوِيلًا }
\end{aligned}
$$

\subsection{Mâ el-Kâffe (مَا الَْكَافَّة)}

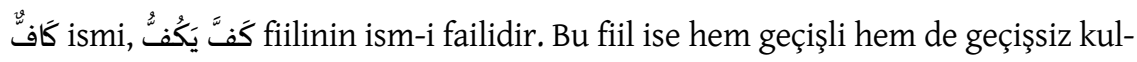
lanılmak üzere vaz geçmek, vaz geçirmek anlamlarına gelir. ${ }^{6}$ Nahvî bir kavram olarak ise kendisinden sonra geldiği harfin veya fiilin amelini iptal etme anlamında kullantlir ve حَرْف كَافُ olarak isimlendirilir. Mâ el-kâffe, zâid bir harftir; fakat zâid olarak isimlendirilmesi, nahvî bir isimlendirmedir ve hiçbir görev ve anlam üstlenmediği anlamina gelmez.

Bu harf; genellikle anlamı güçlendirmek ve pekiştirmek için kullanılır. ${ }^{7}$ Bu bilgiler ışığında kullanıldığı yerler şöyledir:

$\sqrt{ }$ İnne ve benzerlerinden sonra gelebilir. Bu durumda bir belagat terimi olarak "kasr" anlamı ifade eder. ${ }^{8}$

3 Mustafâ b. Muhammed Selîm el-Galâyînî, Câmi'u'd-durûsi'l-'Arabiyye (Beyrut: el-Mektebetü'l-'Asriyye, 1414/1993), 3/254.

4 Cemâluddin Osman b. Ömer b. Ebî Bekr b. Yunus İbnu'l-Hâcib, el-Kâfiye fi 'ilmi'n-nahv, thk. Salih Abdul'azîm eş-Şấir (Kahire: Mektebetü'l-Âdâb, 2010), 47-48.

5 Muhammed b. Abdurrahim el-Meylânî, Şerhu'l-muğnî (İstanbul: Şifa Yayınevi, 2012), 66.

6 Ebû Nasr İsmail b. Hammâd el-Cevherî, es-Sihâh tâcu'l-luğa ve sihâhu'l-'Arabiyye, thk. Ahmed Abdulğafûr 'Attâr (Beyrut: Dâru'l-'illm li'l-Melâyîn, 1407/1987), "Kefefe”, 4/1423; illyas Karslı, Yeni Sözlük: ArapçaTürkçe (ìstanbul: Ensar Neşriyat, 2013), 1865.

7 Râcihî, et-Tatbîku'n-nahvî, 164.

8 Seyyid Ahmed el-Hâşimî, Cevâhiru'l-belâğa fi'l-me'ânî ve'l-beyân ve'l-bedî̀, thk. Yusuf es-Sumeylî (Beyrut: el-Mektebetü'l-'Asriyye, 1434/2013), 168. 


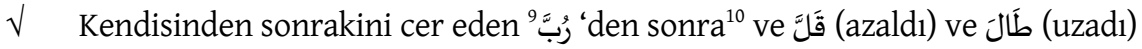
gibi fiillerden sonra gelebilir. Bu durumda bu fiiller faile ihtiyaç duymaz: ${ }^{11}$

$\sqrt{ }$ Örnekler:

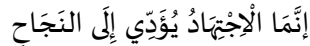

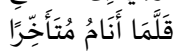

Çalışma, ancak başarıya götürür.

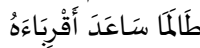

Nadiren geç uyurum.

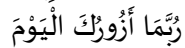

Akrabalarına ne kadar çok yardım etti.

Belki bugün seni ziyarete gelirim.

\subsection{Mâ ez-Zâide (مَا الزَّائدَدةُ)}

Belirtilen hususlara ek olarak o harfinin zâid olarak da gelebilmesi söz konusudur. Zâid olan ما harfini, bir önceki başlıkta ele alınan mâ el-kâffe'den ayıran husus, zâid olan ما harfinin kendisinden önce gelen âmilin amelini iptal etmemesidir. Başka bir deyişle, zâid olan ما harfi, kendisinden önce gelen âmilin ameline etki etmez. ${ }^{12}$ Bununla birlikte mâ el-kâffe bahsinde belirtildiği gibi, "zâid" ifadesinden kastedilen şey, herhangi bir görev veya anlam ifade etmemesi değil; aksine nahvî bir terim olmasidır. Örnek:
قَلَيلًا مَا يَدْرُسُ الْكَسُولُ
Tembel kişi, ne kadar az ders çalışır.

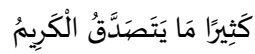
Cömert kişi, ne kadar çok sadaka verir.

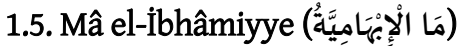

Tanımlanan anlam ve görevlerinin yanı sıra o harfi, nekira bir isimden sonra nekiralık anlamını pekiştirmek için de kullanılabilir. Böylelikle bu görev ve anlamda kullanılan o harfi, kendisinden sonra geldiği nekira isme sıfat olur. ${ }^{13}$ Örnekler:

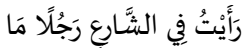
Sokakta (herhangi) bir adam gördüm.

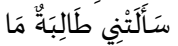
(Herhangi) bir kız öğrenci bana sordu.

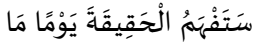
Günün birinde gerçeği anlayacaksın.

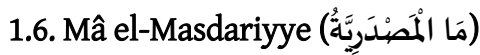

Arapçada masdarlar ikiye ayrılır. Bu bağlamda, tek bir kelime olarak gelen masdarlar ve birden fazla kelimenin bir araya gelmesiyle meydana gelen masdarlar olarak sinıflandırılabilir. Birden fazla kelimenin bir araya gelmesiyle oluşan masdarlara masdar-1 müevvel denir. Masdar-1 müevvel, masdar harfi ve fiil veya masdar harfi ve cümlenin bir araya gelmesiyle oluşur. Masdar harflerinden biri de ما harfidir. ${ }^{14}$

\footnotetext{
رُبَّ , harf-i cer olup nekiradan önce gelir ve bir şeye müteallik olmaz. Ayrıca “azlık” anlamı ifade eder.

10 Ahmed Muhtar Ömer, Mu'cemu'l-luğati'l-'Arabiyyeti'l-mu'âsıra (Kahire: ‘Âlemu'l-Kutub, 1429/2008), $3 / 2059$.

11 Râcihî, et-Tatbîku'n-nahvî, 207.

12 Rummânî, Menâzili'l-hurûf, 63.

13 Galâyînî, Câmi'u'd-durûsi'l-'Arabiyye, 3/223.

14 Mustafa Meral Çörtü, Sarf-Nahiv Edatlar (İstanbul: Marmara Üniversitesi İlahiyat Fakültesi Vakfi Yayınlar1, 2008), 160-167; Mustafa Meral Çörtü, Arapça Cümle Kuruluşu ve Tercüme Tekniği (İstanbul: Marmara Üniversitesi İlahiyat Fakültesi Vakfı Yayınları, 2012), 27-33.
} 
Burada öne çıkan nokta; L edatı masdar harfi olarak kullanıldığında hem mazi hem muzari fiil ile birlikte gelebilmesidir. Böylece masdar olan to harfinden sonra gelen cümleye sıla cümlesi denir ve bu sıla cümlesinde âid zamir yoktur. ${ }^{15}$ Bunun

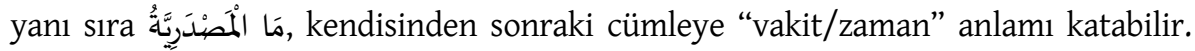

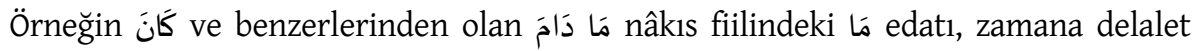

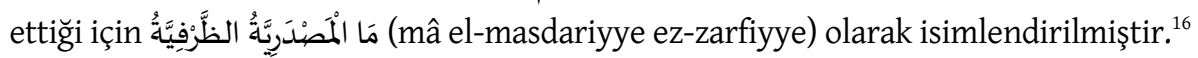
Örnekler:
عَجْبْتُ مِمَّما تَقُولُ
Söylediğin şeye şaşırdım/yadırgadım.

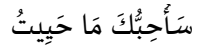
Yaşadığım sürece seni seveceğim.
سَأَعْمَلُ الْخَيْرَ مَا دُمْتُ حَيَّا
Yaşadığım sürece iyilik yapacağım.

\section{2. İsim Olarak Kullanılan ما Edatı}

Önceki bölümde L edatının harf olarak kullanımları incelenmiștir. Bu bölüm ise isim olarak kullanımlarını ele almaktadır. Bu bağlamda م edatının isim olarak dört farklı görev ve anlamda kullanılmakta olduğu vurgulanmaktadır.

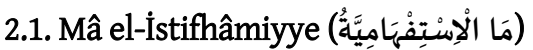

Arapçada ikisi harf, yedisi isim olmak üzere dokuz soru edatı bulunmaktadır. ${ }^{17} \mathrm{Bu}$ edatlardan biri olan w edatı isim kabul edilmektedir. ${ }^{18} \mathrm{Bu}$ açıdan bakıldığında L soru ismi, isimden önce gelebildiği gibi, cümleden önce de gelebilir ve bu cümle, isim cümlesi, fiil cümlesi ve şibih cümle olabilir. Ayrıca lo/Mâ soru ismi, cümledeki yerine göre farklı şekillerde irab olunur: ${ }^{19}$ Bunlar şu şekilde sınıflandırılabilir:

1. Mübteda: İsim cümlesi, fiil cümlesi ve şibih cümleden önce gelirse.

2. Haber-i mukaddem: İsimden önce gelirse.

3. Mefulün bih: Fiil cümlesinden önce gelirse.

Örnekler:

$$
\begin{aligned}
& 20 \text { مَا فِي الْفُرْفَفَ؟؟ }
\end{aligned}
$$

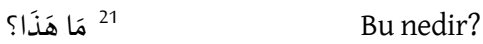

$$
\begin{aligned}
& 22 \text { مَا سَمِمْتَ الْيَوْمَ؟ }
\end{aligned}
$$

Bununla beraber م soru isminden önce harf-i cer gelirse, L edatının elifi vucûben hazfedilir. ${ }^{23}$

Örnek: عَمَّ تَتَحَدَُّ ؟ (Neyden bahsediyordun?), إِلَاََ تَنْظُرُ (Neye bakıyorsun?).

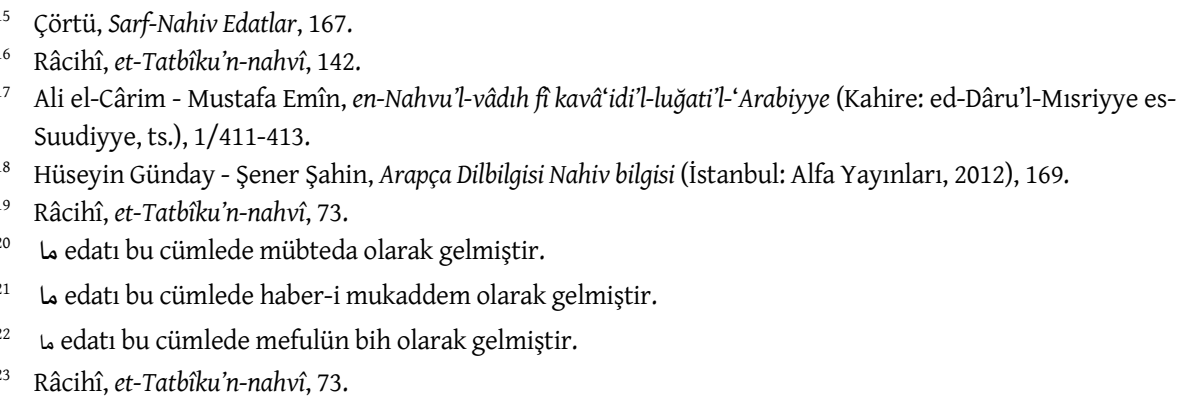




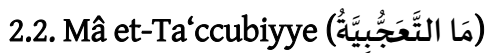

Bilindiği üzere taaccub üslubu, şaşırma ve beğenme gibi duyguları ifade etmede

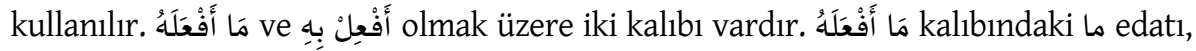
taaccub ismidir. ${ }^{24}$ Genel görüşe göre ما, mübteda merfû olup, kendisinden sonra gelen cümle ref mahallinde haberdir. ${ }^{25}$ Örnekler:

$$
\begin{aligned}
& \text { مَا مَأَجْمَلَ الْجَوَّب }
\end{aligned}
$$

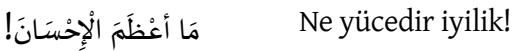

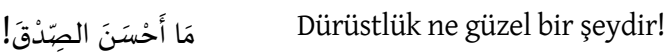

\subsection{Mâ eş-Şartiyye (مَا الشَّْرْطِيَّة)}

Muzari fiili cezmeden şart isimlerinden biri ما edatıdır. Bu edat, cümle içindeki konumuna göre farklı şekillerde irab olunmaktadır. ${ }^{26}$ Bu kapsamda konu iki başlık halinde açılanabilir:

- Ref mahallinde mübteda olarak geldiği durumlar:

1. Kendisinden sonra lazım bir fiil gelirse. Örnek: مَا يَحْدُثْ فِي الشَّرِكَة يَعْلَمْهُ المُدِيرُ (Müdür, şirkette olan biten her şeyi bilir.)

2. Kendisinden sonra mefulün bihi zikredilmiş müteaddî bir fiil gelirse. Örnek: مَ تَفْعَلْهُ تُجَزْ عَلَيِِْْ (Yaptığın şeyin karş1lığın alırsın.)

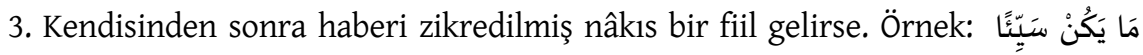
فَاجْتَنْبُُْ (Kötü olan şeyden uzak dur.)

- Nasb mahallinde geldiği durumlar:

1. Kendisinden sonra, haberi zikredilmemiş nâkıs bir fiil gelirse. Örnek: مَا تَكُنْ دَرَجَةُ [Sorumluluğunun düzeyi ne olursa olsun, sen (yine de) hesap verirsin.]

2. Kendisinden sonra, mefulün bihi zikredilmemiş müteaddî bir fiil gelirse. Örnek: مَا تَقْرَاً مِنْ كُتُبِ مُخْتَلِفَةٍ تَزْدَدْ مَعَرِفَتُكَ (Farklı kitaplar okudukça bilgin artar.)

\subsection{Mâ el-Mevsûle (ما الموصهولة)}

Müşterek ism-i mevsullerden sayılan bir ism-i mevsul olan s edatı; genellikle gayr-i âkiller için, nadiren âkiller için kullanılmaktadır ${ }^{27}$ Cümle içindeki konumuna göre farklı şekillerde irab olunur. ${ }^{28} \mathrm{Bu}$ durum üç başlık halinde açıklanabilir:

24 Nedîm Hüseyin Da'kûr, el-Kavấidu't-tatbîkiyye fi'l-luğati'l-'Arabiyye (Beyrut: Muessesetu Bahsûn, 1998), 171.

25 Emre Çavdar, Arap Dili'nde "Lâm”, "Lâ", "Mâ" Edatları ve Kur'ân-ı Kerim'deki Kullanımları (Konya: Necmettin Erbakan Üniversitesi, Doktora Tezi, 2015), 158; Hasan b. Kasım el-Murâdî, el-Cenâ ed-dânî fî hurûfi'méânî, thk. Fahruddîn Kabâve - Muhammed Nedîm Fâdıl (Beyrut: Dâru'l-Kutubi'l-'ilmiyye, 1413/1992), 337.

26 Çavdar, Arap Dili’nde “Lâm”, "Lâ", "Mâ” Edatları ve Kur'ân-ı Kerim'deki Kullanımları, 156.

27 Galâyînî, Câmi'u'd-durûsi'l-'Arabiyye, 1/133.

${ }^{28}$ Çavdar, Arap Dili’nde “Lâm”, "Lâ", "Mâ" Edatları ve Kur'ân-ı Kerim'deki Kullanımları, 150-151. 


\section{1- Ref mahallinde geldiği durumlar:}

a. Mübteda. Örnek: مَا سَمِعْتَهُ صَحِيحُ (Duyduğun şey doğrudur).

b. Haber. Örnek: هَذَا مَا أَقْهِهِدُهُ (Kastettiğim şey budur).

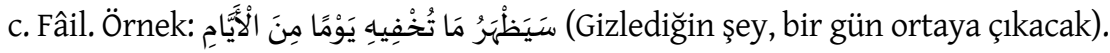

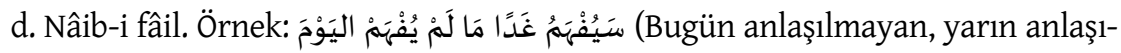
lacak).

\section{2- Nasb mahallinde geldiği durum:}

a. Mefulün bih. Örnek: إنَتَتَيْتُ مَا أَعْجَبَنِ (Hoşuma giden şeyi satın aldım).

\section{3- Cer mahallinde geldiği durumlar:}

a. Muzafun ileyh. Örnek: قُلْتُ لَكَ كُلَّ مَا أَعْرِفُهُ (Bildiğgim her şeyi sana söyledim).

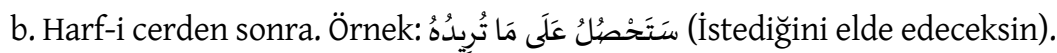

\section{Amme Cüzünde Geçen L Edatının Çeşitleri}

Konu çerçevesinde yapılan araştırmada o edatının, "Amme" cüzünde farklı anlamları ve farklı irab görevlerini ifa etmek üzere 70 defa zikredildiği tespit edilmiştir. Buna ek olarak, Amme cüzünde geçen bazı L edatlarının irabı konusunda, nahiv ve irab âlimlerinin ittifak ettikleri görülse de bu konuda ise farklı görüşlerin söz konusu olduğu dikkat çekmektedir. Farklı görüşlerin çoğunda ise, L edatının birçok şekilde irab olunabileceği ihtimalinin zikredildiği görülmektedir. Bu kapsamda öne çıan bir nokta, araştırmanın birinci bölümünde yer alan L edatı türlerinden olan mâ eşşartiyye ve mâ el-ibhâmiyye'nin amme cüzünde yer almadığı tespit edilmiştir.

Çalışma çerçevesinde elde edilen bilgilere dayanarak Amme cüzünde yer alan edatının zikredildiği durumlar şöyle sıralanabilir:

\subsection{Tek Bir Anlama Delalet Eden L Edatları}

Bu bölümde yer alan ve "tek bir şekilde irab olunan to edatlarından" kastedilen, irabı ve delaleti konusunda ihtilaf bulunmayan o edatı türleridir.

\subsubsection{Mâ en-Nâfiye (مَا النَّافِيَة)}

Mâ en-nâfiye, Amme cüzünde dokuz defa geçmektedir ve irabı konusunda nahiv âlimleri arasında ittifak söz konusudur: $:^{29}$

\begin{tabular}{|c|c|c|c|}
\hline Örnek & Sûre & Âyet & Türkçe Meâli \\
\hline 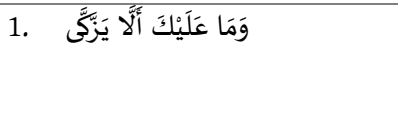 & Abese & 7 & $\begin{array}{l}\text { (İstemiyorsa) onun } \\
\text { arınmamasından } \\
\text { sana ne! }\end{array}$ \\
\hline
\end{tabular}

Ebü'l-Bekā Abdullāh b. el-Hüseyn el-Ukberî, et-Tibyân fí írâbi'l-Kur'ân, thk. Ali Muhammed el-Bicâvî (Kahire: Mektebetü Îsâ el-Bâbî el-Halebî, ts.), 2/1266-1297; Muhyiddîn Dervîş, i'râbu'l-Kur'ân ve beyânuh (Dımeşk: Dâru ìbn Kesîr, 1994), 10/350-542; Kasım Humeydân Da'âs, I'râbu'l-Kur'âni'l-Kerîm (Dımeşk: Dâru'l-Munîr, 2004), 3/414-460; Ahmed b. Muhammed Harrât, el-Muctebâ min muşkili írâbi'l-Kur'ân (Medine: Mecma'u'l-Melik Fehd, 2005), 4/1407-1472. 


\begin{tabular}{|c|c|c|c|}
\hline 2. وَما تَشَاؤنَ إِلاًَ أَنْ يَشَاءَ اللَّهُ & Tekvîr & 29 & $\begin{array}{l}\text { Allah dilemedikçe } \\
\text { siz dileyemezsiniz. }\end{array}$ \\
\hline 3. & Mutaffifîn & 12 & $\begin{array}{l}\text { Onu, ancak her } \\
\text { azgın, günahkâr } \\
\text { kimse inkâr eder. }\end{array}$ \\
\hline 4. وَما أُرْبِلُوِوا عَلَيْهِهْ حافِظِينَ & Mutaffifîn & 33 & $\begin{array}{l}\text { Hâlbuki onlar, } \\
\text { mü'minlerin başına } \\
\text { bekçi olarak gönde- } \\
\text { rilmemişlerdi. }\end{array}$ \\
\hline 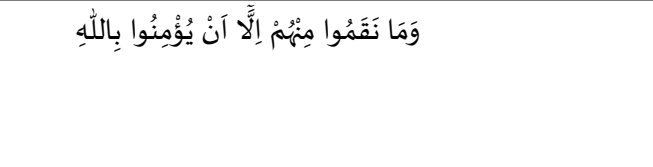 & Burûc & 8 & $\begin{array}{l}\text { Onlar mü'minlere } \\
\text { ancak; Allah'a iman } \\
\text { ettikleri için kızı- } \\
\text { yorlardı. }\end{array}$ \\
\hline 5. ومَا لِأَحَدٍ عِنْدَهُ مِنْ نِعْمَةٍة تُجْزَى & Leyl & 19 & $\begin{array}{l}\text { O, hiç kimseye } \\
\text { karşıllı bekleyerek } \\
\text { iyilik yapmaz. }\end{array}$ \\
\hline 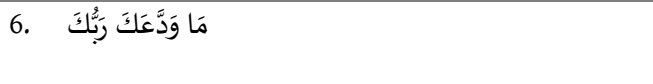 & Duhâ & 3 & $\begin{array}{l}\text { Rabbin seni terk } \\
\text { etmedi. }\end{array}$ \\
\hline 7. وَمَا قَلَى & Duhâ & 3 & Sana darilmadi da. \\
\hline 8. & Beyyine & 4 & $\begin{array}{l}\text { Kendilerine kitap } \\
\text { verilenler, ancak } \\
\text { kendilerine o apaçk } \\
\text { delil geldikten } \\
\text { sonra ayrilığa düş- } \\
\text { tüler. }\end{array}$ \\
\hline 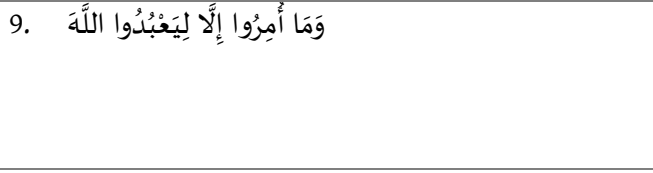 & Beyyine & 5 & $\begin{array}{l}\text { Hâlbuki onlara, } \\
\text { ancak Allah'a kulluk } \\
\text { etmeleri emredil- } \\
\text { mişti. }\end{array}$ \\
\hline
\end{tabular}

\subsection{2. مَا الْعَامِلَةُ عَمَلَ لَيْسنَ) ما Gibi Amel Eden}

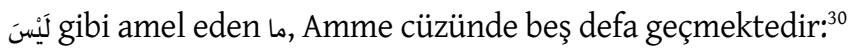

\begin{tabular}{|c|c|c|c|}
\hline Örnek & Sûre & Âyet & Türkçe Meâli \\
\hline 1. وَمَا صَاحِبُكُمْ بِمَجْنُوِِن & Tekvîr & 22 & Sizin arkadaşınız (Muhammed) bir deli değildir. \\
\hline 2. وَما هُوَ عَلَى الْغَيَبِب بِضَنَنِينِ & Tekvîr & 24 & 0 , gayb hakkında cimri değildir. \\
\hline 3و وَما هُوَ بِقَوْلِ شَيْطانٍ & Tekvîr & 25 & Kur'an, kovulmuş şeytanın sözü değildir. \\
\hline 4و وَما هُمْ عَنْها بِغَائِبينَ & İnfitâr & 16 & $\begin{array}{l}\text { Onlar oradan kaybolup kurtulacak da değiller- } \\
\text { dir. }\end{array}$ \\
\hline 5. وَمَا هُوَ بِالْهَزْلِل & Târık & 14 & o, boş bir söz değildir. \\
\hline
\end{tabular}

30 Dervîş, I'râbu'l-Kur'ân ve beyânuh, 10/396-443; Da'âs, I'râbu'l-Kur'âni'l-Kerîm, 3/423-438; Harrât, el-Muctebâa min muşkili i'râbi'l-Kur'ân, 4/1424-1442. 


\subsubsection{Mâ el-Kâffe (مَا الْكَافَّةُ)}

Mâ el-kâffe, Amme cüzünde üç defa geçmektedir. Bulunduğu üç yerde de ismini nasb, haberini ref' yapan inne (إِنَّ)'den sonra gelmiştir: ${ }^{31}$

\begin{tabular}{|c|c|c|c|}
\hline Örnek & Sûre & Âyet & Türkçe Meâli \\
\hline 1. فَإنَّما هِيَ زَجْرَةُ واحِدَدَّة & Naziât & 13 & $\begin{array}{l}\text { Hâlbuki o, bir haykurıştan (sûr'un üfürülmesin- } \\
\text { den) ibarettir. }\end{array}$ \\
\hline 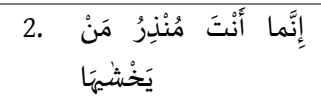 & Naziât & 45 & Sen, ancak ondan korkanları uyarıcısın. \\
\hline
\end{tabular}

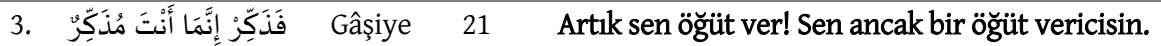

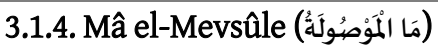

Mâ el-mevsûle, Amme cüzünde on üç farklı yerde zikredilmiştir. Geçtiği bazı yerlerde mahallen mansûb olarak mefulün bih şeklinde, bazı yerlerde ise mahallen merfû olarak fail şeklinde gelmiştir. ${ }^{32}$

\begin{tabular}{|c|c|c|c|}
\hline Örnek & Sûre & Âyet & Türkçe Meâli \\
\hline 1. رَبِّ السَّمَوَاتِ وَالْأْرَضِ وَمَا بَيْنَهمَتا & Nebe & 37 & $\begin{array}{l}\text { Göklerin ve yerin ve ikisi arasındaki- } \\
\text { lerin rabbinden... }\end{array}$ \\
\hline 2. يَوْمَ يَنْظُرُ المْرَءُ ما قَدََّمَتْ يَداهُ & Nebe & 40 & $\begin{array}{l}\text { Kişinin önceden elleriyle yaptıklarına } \\
\text { bakacağı günde... }\end{array}$ \\
\hline 3. كَلَّل لمَّا يَقْضِ مَا أَمَرهُ & Abese & 23 & $\begin{array}{l}\text { Hayır hayır o, Allah'in kendisine } \\
\text { emrettiğini yerine getirmedi. }\end{array}$ \\
\hline 4. عَلمَتْت نَفْسُ ما أَحْضَرَتْتُ & Tekvîr & 14 & $\begin{array}{l}\text { Herkes önceden hazırlayıp getirdiği } \\
\text { şeyleri bilecektir. }\end{array}$ \\
\hline 5. & İnfitâr & 5 & $\begin{array}{l}\text { Herkes yaptığı ve yapmadığı şeyleri } \\
\text { bilecek. }\end{array}$ \\
\hline 6. يَعْلَمُونَ مَا تَفْعَلُونَ & İnfitâr & 12 & Onlar yapmakta olduklarınızı bilirler. \\
\hline 7. هَلْ ثُوِّبَ الْكُفَّارُ ما كانُوا يَفْعَلُونَ & Mutaffifin & 36 & $\begin{array}{l}\text { Nasıl, kâfirler yapmakta olduklarının } \\
\text { karşılığını buldular mı? }\end{array}$ \\
\hline 8. وَأَلْقَتْت ما فِهها وَتَخَلَّتَتْ & İnşikâk & 4 & İçindekileri atıp boşaldığı zaman. \\
\hline 9. & A'lâ & 7 & Ancak Allah'ın dilediği başka. \\
\hline 10. إِنَّهُ يَعْلَمُ الْجْهَهُرَ وَمَا يَخْفَىَى & A'lâ & 7 & $\begin{array}{l}\text { Şüphesiz O, açık olanı da bilir, gizliyi } \\
\text { de. }\end{array}$ \\
\hline 11. & Âdiyât & 9 & $\begin{array}{l}\text { Acaba o bilmiyor mu ki, kabirlerde } \\
\text { bulunanlar çıkarıldı̆̆ı zaman. }\end{array}$ \\
\hline 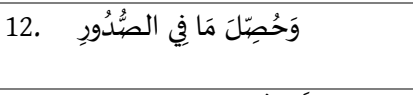 & Âdiyât & 10 & $\begin{array}{l}\text { Ve kalplerdeki ortaya konulduğu } \\
\text { (zaman). }\end{array}$ \\
\hline عَلَّمَ الْإِنْسَانَ مَا لَمْ يَعْلَمْ 13. & Alak & 5 & (0) insana bilmediğini öğretendir. \\
\hline
\end{tabular}

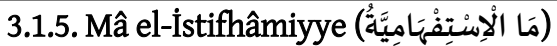

Mâ el-istifhâmiyye, Amme cüzünde on yedi farklı yerde zikredilmiştir. Geçtiği yerlerdeki irabı konusunda bir ihtilafın söz konusu olduğuna rastlanılmamıştır. ${ }^{33}$ 


\begin{tabular}{|c|c|c|c|}
\hline Örnek & Sûre & Âyet & Türkçe Meâli \\
\hline 1. & Nebe & 1 & Birbirlerine neyi soruyorlar? \\
\hline 2. وَمَا يُدْرِيكَ لَعَلَّهُ يَزَّكَّى & Abese & 3 & Ne biliyorsun, belki arınacaktı? \\
\hline 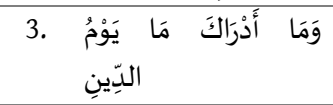 & İnfitâr & 17 & $\begin{array}{l}\text { Hesap ve ceza gününün ne olduğunu sen ne } \\
\text { bileceksin? }\end{array}$ \\
\hline 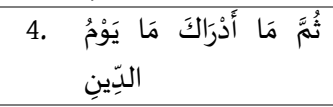 & İnfitâr & 18 & $\begin{array}{l}\text { Evet, hesap ve ceza gününün ne olduğunu sen } \\
\text { ne bileceksin? }\end{array}$ \\
\hline 5. وَمَا أَدْرَالكَ مَا سِجِجِينْن & Mutaffifîn & 8 & Siccîn"in ne olduğunu sen ne bileceksin. \\
\hline 6. وَمَا أَدْرَاكَكَ مَا عِلِيَّونَن & Mutaffifîn & 19 & İlliyyûn"un ne olduğunu sen ne bileceksin \\
\hline 7. وَمَا أَدْرَاكَ & Târık & 2 & Ne olduğunu sen ne bileceksin? \\
\hline 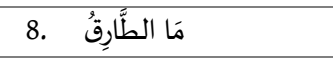 & Târık & 2 & Târıkın ne olduğunu (sen ne bileceksin). \\
\hline 9. فَمَا لَهُهمْ لَا يُؤْمِنُونَن & İnşikâk & 20 & $\begin{array}{l}\text { Böyleyken onlara ne oluyor da iman etmiyor- } \\
\text { lar? }\end{array}$ \\
\hline 10. & Beled & 12 & Sarp yokuşun ne olduğunu sen ne bileceksin? \\
\hline 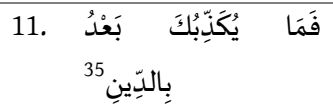 & Tîn & 7 & $\begin{array}{l}\text { (Ey insan!) Böyle iken, hangi şey sana hesap } \\
\text { ve cezayı yalanlatıyor? }\end{array}$ \\
\hline 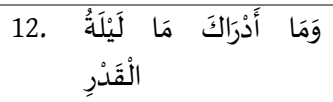 & Kadir & 2 & $\begin{array}{l}\text { Kadir gecesinin ne olduğunu sen ne bilecek- } \\
\text { sin! }\end{array}$ \\
\hline 13. وَقَالَ الِْإنسنَانُ مَا لَهَا & Zilzâl & 3 & İnsan, “Ona ne oluyor?" dedi(ği zaman). \\
\hline 14. مَا الْقارعَعَةُ & Kâria & 2 & Nedir o yürekleri hoplatan büyük felaket? \\
\hline 15. وَما أَدْراكَ & Kâria & 3 & $\begin{array}{l}\text { Yürekleri hoplatan büyük felaketin ne oldu- } \\
\text { gunu sen ne bileceksin? }\end{array}$ \\
\hline 16. 16 وَمَا أَدْرَاكَ مَا هِيََهْ & Kâria & 10 & Sen Hâviye'nin ne olduğunu ne bileceksin? \\
\hline 17. & Hümeze & 5 & Hutame'nin ne olduğunu sen ne bileceksin? \\
\hline
\end{tabular}

\subsubsection{Mâ el-Masdariyye (مَا الْمَصْنَدَرَبَّةُ}

Bu çeşit bir kullanım, amme cüzünde birçok yerde gözlenmiştir, fakat bu konuda görüşlerin yer aldığı irab kitapları arasında ihtilaf söz konusudur. Bu bağlamda edatının masdar harfi olduğu konusunda üzerinde ittifak edilen ayet ise Beyyine suresinin 4. Ayetidir: مِنْ بَعْدِ مَا جَاءَتْهُم الْبَيَنَنُة "Kendilerine o apaçık delil geldikten sonra."

33 Dervîş, I'râbu'l-Kur'ân ve beyânuh, 10/350-579; Da'âs, I'râbu'l-Kur'âni'l-Kerîm, 3/414-468; Harrât, el-Muctebâ min muşkili írâbi'l-Kur'ân, 4/1407-1482.

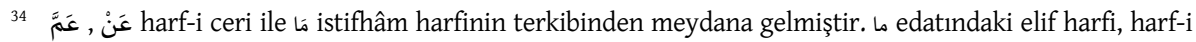
cerden dolayı hazfedilmiştir. Geniş bilgi için bk. Ebû Yûsuf Müntecebüddîn el-Hemedânî, el-Ferîd fi i'râbi'l-Kur'âni'l-mecîd, thk. Muhammed Nizâmuddîn el-Fetîh (Medine: Dâru'z-Zamân, 2006), 6/319; Da'âs, I'râbu'l-Kur'âni'l-Kerîm, 3/414.

35 Bu ayetteki إ edatının irabı ile ilgili el-Ferrâ'nın diğer âlimlerden farklı bir görüşü vardır. Ferrâ, bu ayetteki م edatının نَ anlamında kullanıldığını ifade etmektedir. Bk. Ebû Zekeriyya Yahyâ b. Ziyâd elFerrâ, Me âni'l-Kur'ân, thk. Ahmed Yûsuf en-Necâtî vd. (Kahire: Dâru'l-Misriyye, ts.), 3/277.

36 Dervîş, İ'râbu'l-Kur'ân ve beyânuh, 10/543; Da'âs, İ'râbu'l-Kur'âni'l-Kerîm, 3/460; Harrât, el-Muctebâ min muşkili i'râbi'l-Kur'ân, 4/1472.

37 el-Beyyine 98/4. 


\subsubsection{Mâ et- Ta'ccubiyye (مَا التَّعَجُُبِبيَّةُو)}

Mâ et-ta'ccubiyye, Amme cüzünde sadece bir defa zikredilmiştir ve مَا أَفْعَلَهُ vezninde gelmiştir: ${ }^{38}$

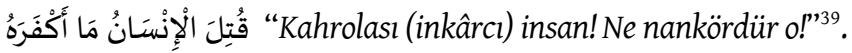

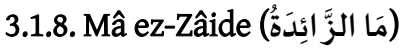

Mâ ez-zâide, Amme cüzünde iki yerde zikredilmiştir. ${ }^{40}$

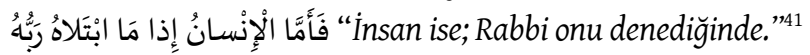

"Ama onu deneyip rızını daraltınca.”42

\subsection{Birden Fazla Anlama Delalet Edebilen ما Edatları}

Bu bölümde, farklı delâletleri söz konusu olan ve irab kitaplarında farklı şekillerde irab olunan odatları ele alınmıştır.

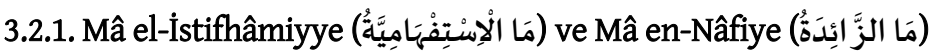

o edatı, Amme cüzünde iki farklı şekilde geçmektedir. Bu kullanımlarda istifhâmiyye ve nâfiye olmak üzere iki farklı delalet mümkün olmaktadır: Bunlardan birincisi şöyledir:

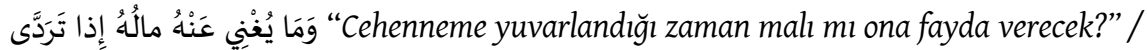

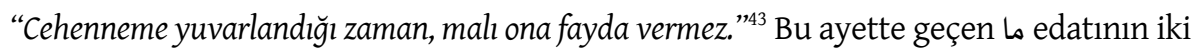
farklı irab ve delaleti söz konusu olabilir. İlki, mâ el-istifhâmiyye anlamında olmasıdır ki bu durumda istifhâm, inkâr anlamına delalet etmiş olur. Zira Arapçada soru edatları bazen aslî anlamından çıkıp farklı anlamlarda kullanılabilir. Bunlardan biri

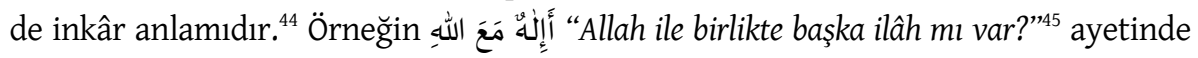
istifhâm, inkâr anlamında kullanılmıştır. İkincisi ise bu ayetteki ما edatının nefy anlamında olmasıdır. ${ }^{46}$ Anlam bakımından iki delalet arasında büyük bir fark söz konusu değildir ve âlimlere göre her iki anlam da caizdir. ${ }^{47}$

Benzer şekilde ikinci ayet de şudur:

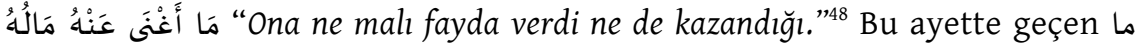
edatı için, istifhâmiyye ve nâfiye delaletlerinin her ikisi de mümkündür. İs-

\footnotetext{
38 Hemedânî, el-Ferîd fì írâbi'l-Kur'âni'l-mecîd, 6/344.

39 Abese 80/17.

40 Mahmûd Abdurrahîm es-Sâfî, el-Cedvel fì i'râbil'l-Kur'ân (Dımeşk: Dâru'r-Raşîd, 1418/1997), 30/324; Harrât, el-Muctebâ min muşkili i'râbi'l-Kur'ân, 4/1451; Da âs, I'râbu'l-Kur'âni'l-Kerîm, 3/445.

41 el-Fecr 89/15.

42 el-Fecr $89 / 16$.

43 el-Leyl 92/11.

44 Hâşimî, Cevâhiru'l-belâğa fi'l-me ânî ve'l-beyân ve'l-bedî, 83.

45 en-Neml 27/60.

46 Da'âs, İrâbu'l-Kur'âni'l-Kerîm, 3/452.

${ }_{47}$ Mekkî b. Ebî Tâlib el-Kaysî, Muşkilu i'râbi'l-Kurân, thk. Hâtim Sâlih ed-Dâmin (Beyrut: Muessetu'r-Risâle, 1405/1985), 2/822.

48 Tebbet $111 / 2$.
} 
tifhâmiyye delaletinde "malı ona ne kazandırdı?" anlamı; nâfiye delaletinde ise "malı ona bir şey kazandırmadı, ona fayda sağlamadı" anlamı ${ }^{49}$ geçerli olur. Her iki anlam da birbirine yakın olup, müfessirler ve dilciler tarafından makbul karşılanmıştır.

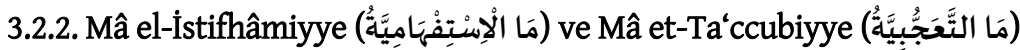

ما edat, Amme cüzünde istifhâmiyye ve ta‘ccubiyye delaletlerinin her ikisinin de mümkün olduğu şekilde sadece bir yerde geçmektedir.

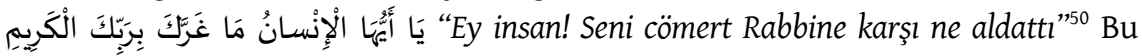
ayetteki ما edatı için istifhâmiyye ta'accubiyye delaletlerinden her ikisi de mümkündür. ${ }^{51}$ İstifhâm delaletinde, o edatı bu ayette "seni Rabbine karşı aldatan şey nedir?" anlamına gelmektedir. Burada istifhâm; istichâl (değer vermemek, önemsememek) ve tevbih (azarlama, ayıplama) anlamlarına delalet etmektedir. Bu ayetteki غَرَََّّ ifadesi, bazı kıraatlere göre مَا أَغَرَََّ şeklinde okunmuştur. Bu durumda, ما edatının, ta'accub anlamına delalet etmesi mümkündür. Anlam ise "Rabbine karşı ne kadar da aldandın" şeklinde olur. ${ }^{52}$ Her iki anlam da delalet bakımından birbirine yakındır. Çünkü ta'accub, bir tür istifham anlamı içermektedir.

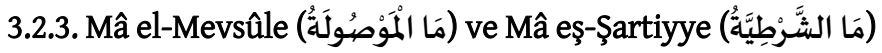

ما edat1, Amme cüzünde mevsûl ve şart delaletlerinin her ikisinin de mümkün olduğu şekilde sadece bir yerde geçmektedir. فِي أَيّ صُورَةٍ مَا شَاءَ رَكَّبَكَ "Dilediği biçimde seni oluşturdu"53

o edatının bu ayette, ism-i mevsûl ve şart edatı anlamına delalet etmesi mümkündür. Her iki delaletin bağlamı ise farklı olur. İsm-i mevsûl anlamına delalet etmesi durumunda, biçimin şekliyle oluşturma anlamlarını birbirine bağlar. Bu durumda anlam "hangi biçimde seni oluşturdu?" şeklinde olur. Şart anlamına delalet etmesi durumunda ise رَكَََّكَكَ ifadesi şartın cevabı olur. ${ }^{54}$ Delalet bağlamı değişse de her iki anlam, insanın Cenab-1 Allah tarafından ne şekilde oluşturulduğu meselesine değinmektedir.

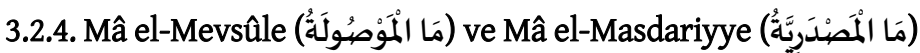

L edatı, Amme cüzünde hem mevsûl hem de masdar delaletlerinin her ikisinin de mümkün olduğu şekilde on beş yerde geçmektedir. Mevsûl ve masdar anlamlarının birbirine yakın olmasından dolayı, tefsir ve i'râb kitaplarında her iki delalet arasında anlam farkının olmadığı görülmektedir. Bu kapsamda o s edatının mevsûl ve masdar

49 İsmail b. Muhammed b. Ali et-Talîhî Ebu'l-Kasım el-İsbahânî, I'râbu'l-Kur'ân (Riyad: Mektebetü'l-Melik Fehd el-Vataniyye, 1995), 560; Hemedânî, el-Ferîd fi i'râbi'l-Kur'âni'l-mecîd, 6/482.

50 el-İnfitâr 82/6.

51 Hemedânî, el-Ferîd fî i'râbi'l-Kur'âni'l-mecîd, 6/354-355; Ebu'l-Kasım Mahmud b. Ömer ez-Zemahşerî, elKeşşâf 'an hakâiki't-tenzîl ve 'uyûni'-ekâvîl fì vucûhi't-te'vîl, thk. Abdurrezzak el-Mehdî (Beyrut: Dâru İhyâi't-Turâsi'l-'Arabî, ts.), 4/716; Dervîş, I'râbu'l-Kur'ân ve beyânuh, 10/402.

52 Hemedânî, el-Ferîd fí írâbi'l-Kur'âni'l-mecîd, 6/354-355.

53 el-ìnfitâr 82/8.

${ }^{54}$ Hemedânî, el-Ferîd fí írâbi'l-Kur'âni'l-mecîd, 6/355. 
delaletlerinin mümkün olduğu ayetler, anlamları ile birlikte özetle şu şekilde arz edilebilir:

1. Hayır hayır! Doğrusu onların kazanmakta oldukları kalplerini paslandırmıştır. ${ }^{.55}$

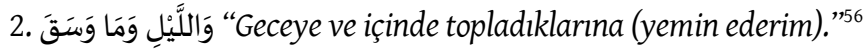

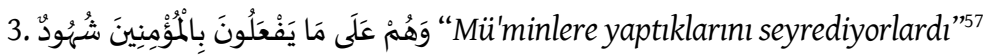

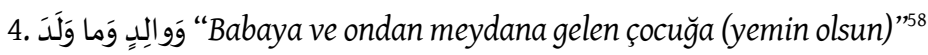

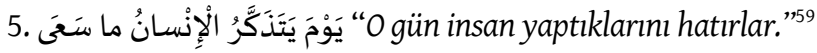

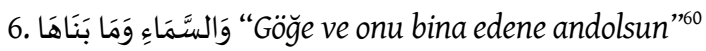

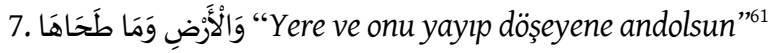

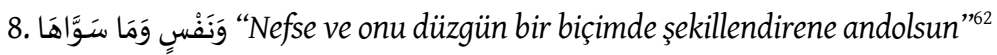

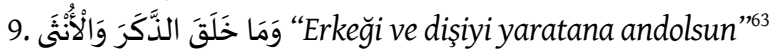

10. Ben sizin kulluk ettiklerinize kulluk etmem"64

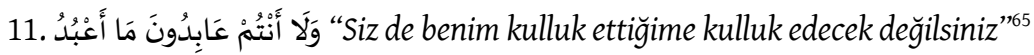

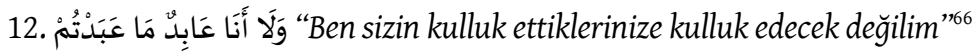

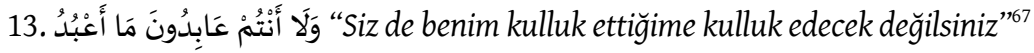

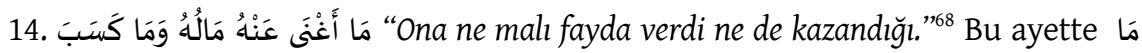
كَسَبَ ifadesindeki ما edatının masdariyye ve mevsûle olmak üzere iki şekilde irab ve delaleti mümkündür ve her iki durumda da anlam aynıdır. ${ }^{69}$

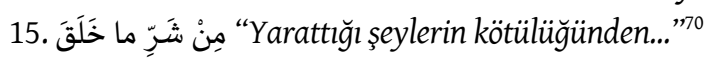

Tüm bunların yanı sıra öne çıkan bir diğer husus; mâ el-masdariyye ile mâ elmevsûle arasındaki farktır. Mâ el-mevsûle genellikle gayr-i âkiller için kullanılan bir mevsûl ismidir. Mâ el-masdariyye ise kendisinden sonra gelen fiil ile birlikte masdar anlamı kazanan bir harftir. Gerek mevsûl harflerinden sonra gerekse de masdar harflerinden sonra bir sila cümlesi bulunur. Mevsûl harflerinden sonra gelen sila

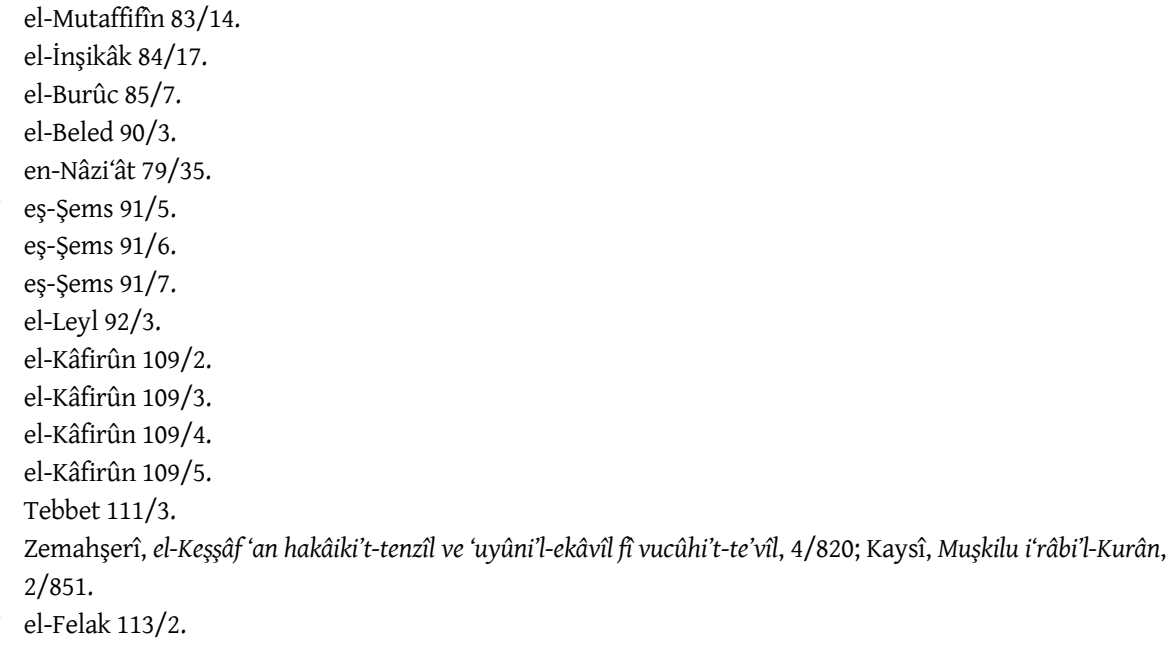


cümlelerinin isim cümlesi veya fiil cümlesi olma durumunda, sıla cümlesinde ism-i mevsûle dönen ister açık ister gizli bir âid zamir bulunurken, ${ }^{71}$ masdar harflerinden sonra gelen sila cümlelerinde âid zamir bulunmaz. ${ }^{72}$

L edatının masdar harfi mi yoksa mevsûl ismi mi olduğunu ayırt etmenin en kolay yolu şudur:

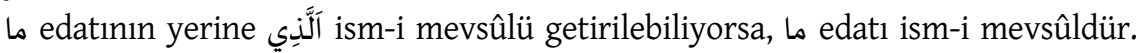

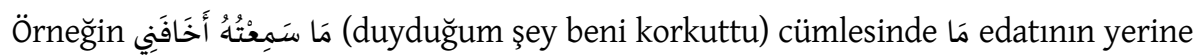
ism-i mevsûlü getirilebilir (آلَّنِي

Diğer taraftan $\mathrm{L}$ edatı ve kendisinden sonraki fiil yerine masdar getirilebiliyorsa, ما edatı masdar harfidir. Örneğin عَجِبْتُ مِمِّا تَقُولُ (Söylediğini yadırgadım/söylediğgin

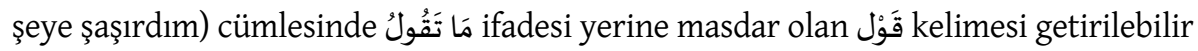
(عَجِبْتُ مِنْ قَوْلكَكَ).

Bunlara ilaveten bazen odatı hem ism-i mevsûl hem de masdar harfi olarak yorumlanabilir. Örneğin أَعَجَبَنِي مَا قُلْنَ (söylediğin şey/söylemen hoşuma gitti) cümle-

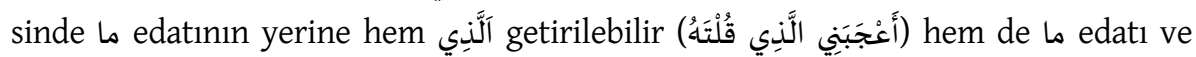

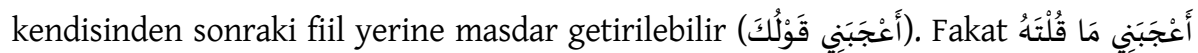
(söylediğin şey hoşuma gitti) cümlesindeki اo edatı, sıla cümlesindeki âid zamirden dolayı sadece ism-i mevsûl olabilir.

\section{Sonuç}

Bu çalışmada, Arapça Dilbilgisi kitapları ve Kur'ân-1 Kerîm'den yararlanılarak konu kapsamında bir araştırma gerçekleştirilmiştir. Bu araştırmaların sonucunda ulaşılan sonuçlar şu şekilde özetlenebilir:

1) Arapçada L edatının -kelime türü bakımından- isim ve harf olmak üzere iki çeşidi vardır. Bu çerçevede; isim ve harf olan to edatının, delalet ettiği anlam yönünden ise on farklı türü vardır. Bu türler şunlardır: Mâ en-nâfiye, "leyse" gibi amel eden mâ, mâ el-kâffe, mâ ez-zâide, mâ el-ibhâmiyye, mâ el-masdariyye, mâ el-istifhâmiyye, mâ et-ta'accubiyye, mâ eş-şartiyye ve mâ el-mevsûle. Burada öne çıkan bir husus; her bir เ türünün cümle içindeki konumuna göre farklı irabı ve anlamının olduğudur.

2) Delalet ettiği anlam bakımından on farklı türü bulunan L edatının altı çeşidi "harf" sınıfına dört türü de "isim" sınıfına dâhil olmaktadır.

3) Harf sınıfına dâhil olan L edatı türleri şunlardır: Mâ en-nâfiye, leyse gibi amel eden mâ, mâ el-kâffe, mâ ez-zâide, mâ el-ibhâmiyye ve mâ el-masdariyye.

4) İsim sınıfına dâhil olan เo edatı türleri ise şunlardır: Mâ el-istifhâmiyye, mâ et-ta‘accubiyye, mâ eş-şartiyye ve mâ el-mevsûle.

\footnotetext{
71 Günday - Şahin, Arapça Dilbilgisi Nahiv bilgisi, 195.

72 Çörtü, Sarf-Nahiv Edatlar, 231.
} 
5) $\quad$ odatı, Amme cüzünde farklı şekillerde ve anlamlarda olmak üzere $70 \mathrm{kez}$ zikredilmiştir. Amme cüzünde geçen o s edatlarıyla ilgili olarak; bazılarının irabı ile ilgili ittifak, bazılarının irabı ile ilgili ise ihtilaf söz konusudur. Bu bağlamda âlimlerin irabı konusunda üzerinde ittifak ettikleri o satının sayısı elli bir; üzerinde ihtilaf ettikleri odatının sayısı ise on dokuzdur.

6) Gerek isim sınıfına gerekse harf sınıfına giren إ edatının -ikisi hâriç bütün türlerinin- Amme cüzünde geçtiği görülmektedir. Bununla birlikte mâ eş-şartiyye ve mâ el-ibhâmiyye'nin Amme cüzünde zikri geçmemektedir.

7) Amme cüzünde en fazla zikri geçen ve irabı konusunda en fazla ittifak bulu-

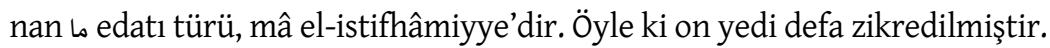

8) Amme cüzünde iki farklı şekilde irab/delalet olunması mümkün olan L edatı türleri ise, mâ el-masdariyye ve mâ el-mevsûle'dir. Her iki şekilde de delalet olunması mümkün olan yer sayısı on beştir.

Sonuç olarak s edatının on farklı türünün bulunması, dil açısından zenginliktir. Bu zenginliğin Kur'ân-1 Kerîm'de eşsiz bir şekilde bulunduğunu belirtmek mümkündür.

\section{Kaynakça}

Cârim, Ali - Emîn, Mustafa. en-Nahvu'l-vâdıh fi kavấidi'l-luğati'l-'Arabiyye. Kahire: ed-Dâru'lMisriyye es-Suudiyye, ts.

Cevherî, Ebû Nasr İsmail b. Hammâd. es-Sihâh tâcu'l-luğa ve sıhâhu'l-'Arabiyye. thk. Ahmed Abdulğafûr Attâr. Beyrut: Dâru'l-'ílm li'l-Melâyîn, 4. Basım, 1407/1987.

Çavdar, Emre. Arap Dilinde "Lâm”, "Lâ", "Mâ" Edatları ve Kur'ân-ı Kerim'deki Kullanımları. Konya: Necmettin Erbakan Üniversitesi, Doktora Tezi, 2015.

Çörtü, Mustafa Meral. Arapça Cümle Kuruluşu ve Tercüme Tekniği. İstanbul: Marmara Üniversitesi İlahiyat Fakültesi Vakfi Yayınları, 8. Basım, 2012.

Çörtü, Mustafa Meral. Sarf-Nahiv Edatlar. İstanbul: Marmara Üniversitesi İlahiyat Fakültesi Vakfı Yayınları, 8. Basım, 2008.

Da âs, Kasım Humeydân. I'râbu'l-Kur'âni'l-Kerîm. Dımeşk: Dâru'l-Munîr, 2004.

Dakûr, Nedîm Hüseyin. el-Kavấidu't-tatbîkiyye fíl-luğati'l-'Arabiyye. Beyrut: Muessesetu Bahsûn, 1998.

Dervîş, Muhyiddîn. İ'râbu'l-Kur'ân ve beyânuh. Dımeşk: Dâru İbn Kesîr, 4. Basım, 1994.

Ferrâ, Ebû Zekeriyya Yahyâ b. Ziyâd. Me âni'l-Kur'ân. thk. Ahmed Yûsuf en-Necâtî vd. Kahire: Dâru'l-Misriyye, ts.

Günday, Hüseyin - Şahin, Şener. Arapça Dilbilgisi Nahiv bilgisi. İstanbul: Alfa Yayınları, 6. Basım, 2012.

Galâyînî, Mustafâ b. Muhammed Selîm. Câmi'u'd-durûsi'l-'Arabiyye. Beyrut: el-Mektebetü'l'Asriyye, 28. Basım, 1414/1993.

Hacibekiroğlu, Abdullah. Arap Dilinde Edatların Metinde Kurduğu Anlamsal İlişkiler. Ankara: Yıldırım Beyazıt Üniversitesi, Doktora Tezi, 2015.

Kurân-ı Kerîm Meâli. çev. Halil Altuntaş, Muzaffer Şahin. Ankara: Diyanet İşleri Başkanlığı Yayınları, 12. Basım, 2011.

Harrât, Ahmed b. Muhammed. el-Muctebâ min muşkili i'râbi'l-Kur'ân. Medine: Mecma'u'l-Melik Fehd, 2005. 
Hâşimî, es-Seyyid Ahmed. Cevâhiru'l-belâğa fi'l-me‘ânî ve'l-beyân ve'l-bedît. thk. Yusuf es-Sumeylî. Beyrut: el-Mektebetu'l-'Asriyye, 1434/2013.

Hemedânî, Ebû Yûsuf Müntecebüddîn. el-Ferîd fî i'râbi'l-Kur'âni'l-mecîd. thk. Muhammed Nizâmuddîn el-Fetîh. Medine: Dâru'z-Zamân, 2006.

İbnu'l-Hâcib, Cemâluddin Osman b. Ömer b. Ebî Bekr b. Yunus. el-Kâfiye fí 'ilmi’n-nahv. thk. Salih Abdulazîm eş-Şâir. Kahire: Mektebetu'l-Âdâb, 1. Basım, 2010.

İsbahânî, İsmail b. Muhammed b. Ali et-Talîhî Ebu'l-Kasım. I'râbu'l-Kur'ân. Riyad: Mektebetu'lMelik Fehd el-Vataniyye, 1995.

Karslı, İlyas. Yeni Sözlük : Arapça-Türkçe. İstanbul: Ensar Neşriyat, 1. Basım, 2013.

Kaysî, Mekkî b. Ebî Tâlib. Muşkilu írâbi'l-Kurân. thk. Hâtim Sâlih ed-Dâmin. Beyrut: Muessetu'rRisâle, 2. Basım, 1405/1985.

Meylânî, Muhammed b. Abdurrahim. Şerhu'l-muğnî. İstanbul: Şifa Yayınevi, 2012.

Murâdî, Hasan b. Kasım. el-Cenâ ed-dânî fî hurûfi'-meeânî. thk. Fahruddîn Kabâve - Muhammed Nedîm Fâdıl. Beyrut: Dâru'l-Kutubi'l-'̇lmiyye, 1. Basım, 1413/1992.

Ömer, Ahmed Muhtar. Mu'cemu'l-luğati'l-'Arabiyyeti'l-mu'âsıra. Kahire: 'Âlemu'l-Kutub, 1. Basım, $1429 / 2008$.

Râcihî, Abduh. et-Tatbîku'n-nahvî. Beyrut: Dâru'n-Nahdati'l-'Arabiyye, 2. Basım, 1431/2010.

Rummânî, Ebü'l-Hasen Alî b. Îsâ b. Alî. Menâzili'l-hurûf. Beyrut: el-Mektebetü'l-'Asriyye, 1. Basim, 2005.

Sâfî, Mahmûd Abdurrahîm. el-Cedvel fí írâbil'l-Kur'ân. Dımeşk: Dâru'r-Raşîd, 1418/1997.

Ukberî, Ebü'l-Bekâ Abdullâh b. el-Huseyn. et-Tibyân fì itrâbi'l-Kur'ân. thk. Ali Muhammed elBicâvî. Kahire: Mektebetü Îsâ el-Bâbî el-Halebî, ts.

Zemahşerî, Ebu'l-Kasım Mahmud b. Ömer. el-Keşşâf 'an hakâiki't-tenzîl ve 'uyûni'-ekâvîl fî vucûhi'tte’vîl. thk. Abdurrezzak el-Mehdî. Beyrut: Dâru İhyâi't-Turâsi'l-'Arabî, ts. 